\title{
Calcium binding to $S$. mutans grown in the presence or absence of sucrose
}

\section{Tarcísio Jorge Leitão(a) Livia Maria Andaló Tenuta ${ }^{(a)}$ Guilherme Ishi(a) Jaime Aparecido Cury(a)}

(a) Department of Physiological Sciences, Piracicaba Dental School, University of Campinas, Piracicaba, SP, Brazil.
Declaration of Interests: The authors certify that they have no commercial or associative interest that represents a conflict of interest in connection with the manuscript.

Corresponding author:

Livia Maria Andaló Tenuta

E-mail: litenuta@fop.unicamp.br

Received for publication on Nov 04, 2011 Accepted for publication on Fev 02, 2012

\begin{abstract}
Sucrose is the most cariogenic dietary carbohydrate because it is a substrate for insoluble extracellular polysaccharide (IEPS) production in dental biofilms, which can proportionally decrease bacterial density and, consequently, the number of biofilm calcium (Ca) binding sites. $\mathrm{Ca}$ bound to bacterial cell walls can be released into the biofilm fluid during a cariogenic challenge, reducing the driving force for mineral dissolution provoked by the $\mathrm{pH}$ drop. Thus, we investigated the effect of an IEPS-rich extracellular matrix on bacterial $\mathrm{Ca}$ binding after treatment with Ca solutions. Streptococcus mutans Ingbritt 1600 was cultivated in culture broths supplemented with $1.0 \%$ sucrose or $0.5 \%$ glucose $+0.5 \%$ fructose. The IEPS concentration in bacterial pellets was determined after alkaline extraction. Bacterial pellets were treated with $1 \mathrm{mM}$ or $10 \mathrm{mM} \mathrm{Ca}{ }^{++}$solutions at $37^{\circ} \mathrm{C}$ for 10 to $60 \mathrm{~min}$. Ca binding to bacterial pellets, determined after acid extraction using the Arsenazo III reagent, was fast and concentration dependent. Although the IEPS concentration was approximately ten times higher in bacterial pellets cultivated in sucrose as compared to its monossaccharides, bound $\mathrm{Ca}$ concentration after $\mathrm{Ca}$ treatment was similar in both conditions. These results suggest that IEPS may not influence the amount of $\mathrm{Ca}$ bound to reservoirs of dental biofilms.
\end{abstract}

Descriptors: Sucrose; Streptococcus mutans; Polysaccharides; Calcium; Dental Caries.

\section{Introduction}

There is considerable evidence demonstrating that sucrose is the most cariogenic carbohydrate from the human diet, ${ }^{1}$ with enhanced cariogenicity as compared to its component monosaccharides, glucose and fructose. ${ }^{2}$ The reason for this relies on the fact that sucrose, besides being fermented to acids, is also used by oral bacteria to synthesize extracellular polysaccharides (EPS). ${ }^{3}$ These EPS, mainly the insoluble ones (IEPS), play a significant role on the adhesion and accumulation of cariogenic streptococci on the tooth surface, especially $S$. mutans.${ }^{4}$ In addition, they change the biofilm structure, resulting in increased porosity, ${ }^{5}$ which allows fermentable substrates to diffuse and be metabolized in the deepest parts of the biofilm. ${ }^{6}$

Furthermore, since IEPS decrease the bacterial density of biofilms, ${ }^{7,8}$ they may reduce the amount of biofilm calcium $(\mathrm{Ca})$ binding sites ${ }^{9}$, which could also influence biofilm cariogenicity. Ca bound to bacterial cell 
walls might function as a source of mineral ions to the biofilm fluid during a $\mathrm{pH}$ drop, ${ }^{9}$ acting as a mineral buffer by helping to maintain the saturation of plaque fluid with respect to tooth mineral, a factor that largely governs its dissolution. ${ }^{10}$

Therefore, we hypothesized that the number of binding sites for $\mathrm{Ca}$ would be reduced in dental biofilm formed in the presence of sucrose, and we investigated this effect by evaluating the rate of $\mathrm{Ca}$ binding to $S$. mutans grown in the presence of sucrose or its component monosaccharides in vitro.

\section{Methodology \\ Experimental design}

S. mutans Ingbritt 1600 was cultivated in the presence of sucrose (to allow the production of extracellular polysaccharides) or its component monosaccharides, glucose and fructose (not substrates for EPS synthesis). Bacterial pellets obtained by centrifugation were analyzed for IEPS, bacterial proteins (as an indicator of bacterial density ${ }^{11}$ ), and baseline $\mathrm{Ca}$. Additional pellets were treated with 1 or $10 \mathrm{mM} \mathrm{Ca}^{++}\left(\mathrm{CaCl}_{2}\right)$, buffered with $0.05 \mathrm{M}$ PIPES (piperazine-N, N'-bis [2-ethanesulphonate]; Sigma Biochemicals), $\mathrm{pH} 7.0$, at $37^{\circ} \mathrm{C}$ for 10,30 , or $60 \mathrm{~min}$. The Ca concentrations used, 1 and $10 \mathrm{mM}$, represent the resting $\mathrm{Ca}$ biofilm fluid concentration ${ }^{12}$ and the high $\mathrm{Ca}$ concentration found in biofilm fluid after a $\mathrm{pH}$ drop, respectively. ${ }^{10}$ After the specified equilibrium time, the bacteria were separated from the test solution by centrifugation, bound $\mathrm{Ca}$ was extracted from the bacterial pellet with acid treatment, and its concentration was determined.

\section{Bacterial preparation}

S. mutans Ingbritt 1600 was cultivated in ToddHewitt broth (THB) (Difco Labs., Detroit, USA) supplemented with $1 \%$ sucrose or $0.5 \%$ glucose $+0.5 \%$ fructose for $18 \mathrm{~h}$ at $10 \% \mathrm{pCO}_{2}$ and $37^{\circ} \mathrm{C}$. Bacterial pellets were separated by centrifugation. In order to remove remnants of culture broth and unbound $\mathrm{Ca}$, the pellets were sequentially washed using sonication (Vibra Cell sonicator, Sonics and Materials, Danbury, USA) at $7 \mathrm{~W}$ for $1 \mathrm{~min}$, first in $0.05 \mathrm{M}$ PIPES buffer, $\mathrm{pH}$ 7.0, followed by $0.01 \mathrm{M}$ EDTA solution, and again in PIPES buffer. ${ }^{9}$ Between each washing, the pellet was recovered by centrifugation. After this procedure, the pellet was spread on filter paper to remove excess moisture. Aliquots were transferred to microcentrifuge tubes for IEPS and protein determination and baseline $\mathrm{Ca}$ and $\mathrm{Ca}$-binding analyses.

\section{IEPS and protein determination in bacterial pellets}

To extract EPS, aliquots $(\mathrm{n}=3)$ of bacterial pellets were weighed $( \pm 0.01 \mathrm{mg})$, suspended in $0.9 \%$ $\mathrm{NaCl}$ solution (1 mL/mg wet weight), sonicated at $7 \mathrm{~W}$ for $60 \mathrm{~s}$, and centrifuged at 10,000 $\mathrm{g}$ for $5 \mathrm{~min}$ at $4^{\circ} \mathrm{C}$ to remove soluble EPS. ${ }^{13}$ IEPS was alkaline extracted from the remaining pellet ${ }^{14}$ and precipitated with ethanol. The carbohydrate concentration in the IEPS extract was estimated by the phenol-sulfuric acid method. ${ }^{15}$

To determine bacterial proteins, aliquots of bacterial pellets $(n=3)$ were first treated with a mild alkaline solution ${ }^{16}$ to remove extracellular proteins, and the supernatant obtained by centrifugation was discarded. The precipitate was treated with a hot alkaline solution to extract bacterial proteins, ${ }^{13}$ whose concentration was determined by the Lowry method. ${ }^{17}$

\section{Ca-binding assessment}

Aliquots of $S$. mutans pellets were exposed to PIPES buffer (1.5 mL/10 mg of bacteria), $\mathrm{pH} 7.0$, containing 1 or $10 \mathrm{mM} \mathrm{Ca}$, for 10,30 , or $60 \mathrm{~min}$ ( $\mathrm{n}=2$ for each time point). The high dilution was used to maintain a stable $\mathrm{Ca}$ concentration during the experiment. At each time point, the pellets were collected by centrifugation (21,000 $\mathrm{g}$ for $5 \mathrm{~min}$ ), and the supernatant was carefully vacuum-aspirated with a micropipette under a microscope to remove any treatment solution residue. The efficacy of residual Ca removal was validated by a preliminary experiment (data not shown) in which the amount of Ca remaining in the bacterial pellet was confirmed to be bound and not simply trapped in the bacterial pellet fluid.

\section{Determination of Ca bound to bacterial cells}

Bound Ca was extracted from the bacterial pel- 
lets by treatment with $0.5 \mathrm{M} \mathrm{HCl}(0.1 \mathrm{~mL} / 10 \mathrm{mg}$ bacterial wet weight) for $3 \mathrm{~h} .{ }^{14}$ The acid extract was collected after centrifugation, and the Ca concentration was measured using the Arsenazo III colorimetric reagent, after neutralization with $2.5 \mathrm{M}$ $\mathrm{NaOH} .{ }^{18}$ For the analyses, Ca standards contained $\mathrm{HCl}$ and $\mathrm{NaOH}$ in the same proportion as the samples. The absorbance of the mixtures was read in 96-well microplates, using a Multiskan Spectrum (Thermo Scientific) microplate reader at $650 \mathrm{~nm}$.

\section{Statistical analyses}

Data of IEPS, bacterial proteins, and baseline $\mathrm{Ca}$ in untreated pellets on biofilms cultivated in the presence of sucrose or glucose + fructose were compared by the $t$-test. Ca binding to the bacterial pellets after treatment with Ca solutions at different times were compared by split plot ANOVA, using cultivation conditions (sucrose or glucose + fructose) as plots and $\mathrm{Ca}$ concentration in the treatment solution $(1$ or $10 \mathrm{mM})$ and time $(10,30$, or $60 \mathrm{~min})$ as subplots. The normality of error distribution and the homogeneity of variance were checked for each response variable using the SAS/LAB package (SAS software, version 8.01, SAS Institute Inc., Cary, USA), and data were transformed as suggested by the software, according to Box et al. ${ }^{19}$ The SAS system (version 9.2) was used in the analyses, and the significance level was set at $5 \%$.

\section{Results}

Comparisons of the composition of bacterial pellets cultivated in the presence of sucrose or glucose + fructose revealed significantly $(p<0.05)$ higher EPS and lower bacterial protein and baseline $\mathrm{Ca}$ concentrations for the former condition (Table 1).

Figure 1 shows that the rate of $\mathrm{Ca}$ binding to the bacterial pellets cultivated either in the presence of sucrose or glucose + fructose was fast, with no significant difference in bound $\mathrm{Ca}$ concentration among the treatment times $(p>0.05)$. Higher $\mathrm{Ca}$ concentrations were found in bacteria treated with $10 \mathrm{mM} \mathrm{Ca}$, as compared to those treated with

Table 1 - Insoluble extracellular polysaccharide (IEPS), protein concentration $(\mathrm{mg} / \mathrm{g}$ wet weight, mean $\pm \mathrm{SD} ; \mathrm{n}=3)$, and baseline $\mathrm{Ca}(\mu \mathrm{mol} / \mathrm{g}$ wet weight, mean $\pm \mathrm{SD}, \mathrm{n}=4)$ in bacterial pellets according to the carbohydrate source used for S. mutans growth.

\begin{tabular}{c|c|c|c}
\hline $\begin{array}{c}\text { S. mutans } \\
\text { carbohydrate source }\end{array}$ & IEPS* & $\begin{array}{c}\text { Bacterial } \\
\text { protein }\end{array}$ & Baseline Ca \\
\hline Sucrose & $52.5 \pm 2.5$ & $39.3 \pm 1.8$ & $0.4 \pm 0.1$ \\
\hline Glucose + fructose & $6.0 \pm 0.2$ & $75.1 \pm 0.5$ & $1.7 \pm 0.3$ \\
\hline
\end{tabular}

* An inverse transformation of the IEPS data was performed to fit the assumptions of the $t$-test. Significant differences were observed between the treatments for all variables analyzed $(p<0.05)$.

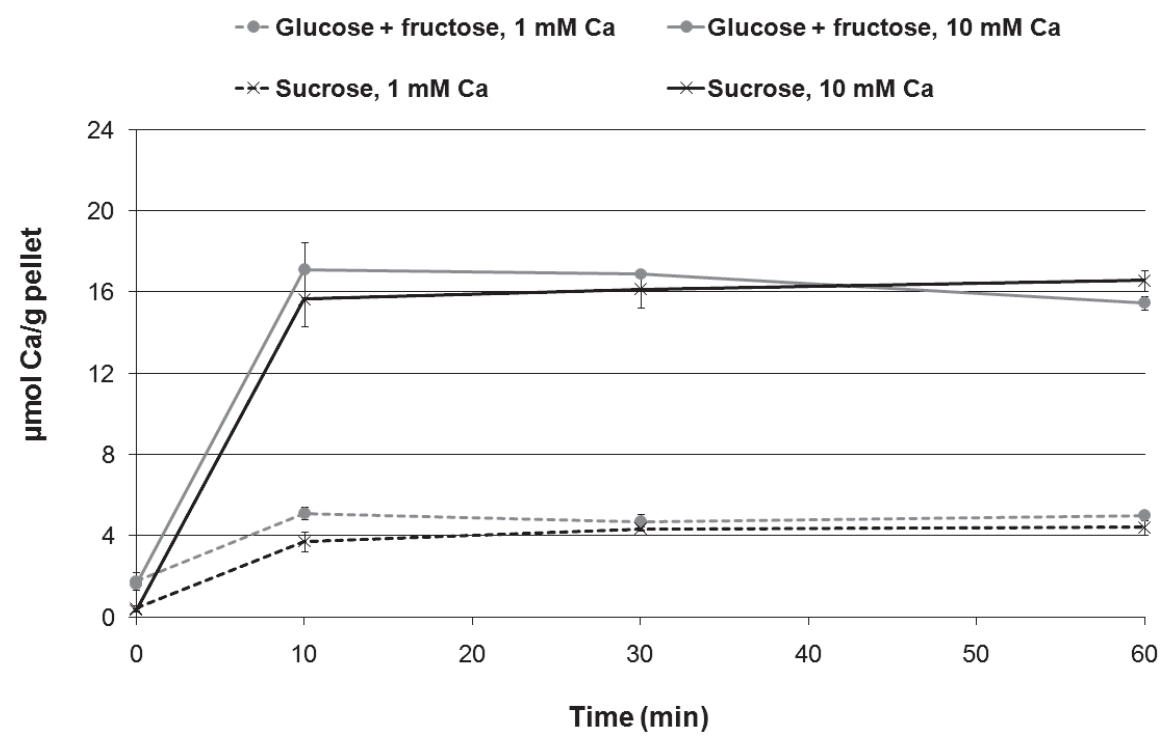

Figure 1 - Bound $\mathrm{Ca}$ concentration $(\mu \mathrm{mol} / \mathrm{g}$ wet weight, mean $\pm S D ; n=2$ for each time point) in bacterial pellets as a function of time, carbohydrate source, and Ca concentration in the treatment solution. Time 0 represents the baseline $\mathrm{Ca}$ amount found in bacterial pellets $(n=4)$. Data were transformed to $\log _{10}$ units for statistical analysis. Only the effect of Ca treatment solutions was found to be significant (split-plot ANOVA, $p<0.05)$. 
$1 \mathrm{mM} \mathrm{Ca}(p<0.05)$. However, the amount of bound $\mathrm{Ca}$ was not significantly different between the two bacterial growth conditions (presence or absence of sucrose) $(p>0.05)$.

\section{Discussion}

In the present study, the concentration of IEPS was approximately 10 times higher in the bacterial pellets cultivated in the presence of sucrose when compared to its monosaccharides (Table 1). These results confirm the ability of this $S$. mutans strain to produce EPS in the presence of sucrose, ${ }^{6,8}$ as a model that simulates what happens in dental biofilm. ${ }^{2}$ Also, the lower protein concentration in bacterial pellets (Table 1) is in agreement with van Houte et al., ${ }^{8}$ who reported decreased bacterial cell density when this $S$. mutans strain was grown in THB supplemented with $2 \%$ sucrose as compared to the same medium with a ten times lower concentration. Considering that proteins from bacterial cell walls are Ca-binding sites, ${ }^{20}$ and EPS does not have this property, ${ }^{9}$ it would be expected that bacterial pellets grown in the presence of sucrose would have a lower ability to bind $\mathrm{Ca}$ per weight of bacteria. Although this was observed for the baseline $\mathrm{Ca}$ concentration in the bacterial pellets (Table 1), the results of $\mathrm{Ca}$ binding after treatment with Ca-containing solutions did not support this hypothesis (Figure 1), and the theoretical support to explain these results is presented below.

The concentration of bound $\mathrm{Ca}$ found after treatment with $\mathrm{Ca}$ solutions is consistent with previous studies of $\mathrm{Ca}$ binding to streptococci strains from solutions with varying $\mathrm{Ca}$ concentrations, ${ }^{21-23}$ in which glucose was used as the carbohydrate source for bacterial growth. However, these authors did not evaluate the effect of different sugars used to cultivate bacteria on Ca binding, especially sucrose, which significantly affects the biofilm extracellular matrix composition. ${ }^{2,3}$ This was the aim of the present study.

Moreover, the results agree with those of previous studies ${ }^{2,12,24}$ that did not find a significant difference in total Ca concentration in biofilms formed in situ in the presence of glucose + fructose when compared to sucrose, suggesting that the IEPS-rich extracellular biofilm matrix is not able to affect whole biofilm Ca binding. In this regard, it is noteworthy that IEPS concentration represents approximately $5 \%$ of the total biofilm wet weight, in agreement with previous in situ studies. ${ }^{2,13,14,24-26}$ This low percentage, supposedly relevant to induce differences between the bacterial pellets on residual $\mathrm{Ca}$ binding capacity, might not be able to significantly affect bound $\mathrm{Ca}$ concentration once the bacteria are treated with $\mathrm{Ca}$-containing solutions (i.e., 1 or $10 \mathrm{mM})$. Furthermore, the results suggest that the EPS concentration is not the reason for the low concentration of inorganic ions $(\mathrm{Ca}$, inorganic phosphorus, and fluoride) found in dental biofilms formed under exposure to sugars, ${ }^{2,3,12-14,24,26}$ suggesting that further research should be done to explain this biological phenomenon.

Nevertheless, an alternative hypothesis to explain our findings is based on the effect of sucrose to enhance the number of Ca-binding sites in bacterial plaque formed in its presence. In vivo studies have shown that dental plaque formed in the presence of sucrose has a higher amount of lipoteichoic acid, ${ }^{27}$ which might enhance Ca-binding capacity because phosphate groups have a higher affinity for $\mathrm{Ca}$ ions than carboxyl groups from proteins present in streptococcus cell walls. ${ }^{20}$ Therefore, in the presence of sucrose, a higher concentration of bacterial cell wall components with higher Ca-binding capacity could be expressed and compensate for the lower bacterial density.

Our Ca-binding kinetics results are consistent with those by Tatevossian, ${ }^{28}$ who studied the kinetics of $\mathrm{Ca}$ binding in a pool of bacterial plaque using $\mathrm{Ca}$ ion-selective electrodes in vitro; this study showed that the binding was rapid and almost reached saturation within $10 \mathrm{~min}$. Although the experimental design used in the present study did not allow for reaction rate determination at times less than 10 min with good precision, the high dilution of the bacterial pellet used ensured that the concentration of the treatment solution did not change as binding occurred.

It should be noted that the importance of bacterial-bound $\mathrm{Ca}$ as a source of $\mathrm{Ca}$ to the biofilm fluid during a $\mathrm{pH}$ drop is subject to further confirmation. 
Thus, not only the binding capacity, but also the kinetics of $\mathrm{Ca}$ release as a function of $\mathrm{pH}$ should be studied in further detail to provide a better understanding of these phenomena in dental plaque in vivo.

\section{Conclusion}

Our data suggest that $\mathrm{Ca}$ binding to bacterial

\section{References}

1. Zero DT. Sugars - the arch criminal? Caries Res. 2004 MayJun;38(3):277-85.

2. Cury JA, Rebelo MA, Del Bel Cury AA, Derbyshire MT, Tabchoury CP. Biochemical composition and cariogenicity of dental plaque formed in the presence of sucrose or glucose and fructose. Caries Res. 2000 Nov-Dec;34(6):491-7.

3. Paes Leme AF, Koo H, Bellato CM, Bedi G, Cury JA. The role of sucrose in cariogenic dental biofilm formation--new insight. J Dent Res. 2006 Oct;85(10):878-87.

4. Bowen WH, Koo H. Biology of Streptococcus mutans-derived glucosyltransferases: role in extracellular matrix formation of cariogenic biofilms. Caries Res. 2011 Apr;45(1):69-86.

5. Dibdin GH, Shellis RP. Physical and biochemical studies of Streptococcus mutans sediments suggest new factors linking the cariogenicity of plaque with its extracellular polysaccharide content. J Dent Res. 1988 Jun;67(6):890-5.

6. Zero DT, van Houte J, Russo J. The intra-oral effect on enamel demineralization of extracellular matrix material synthesized from sucrose by Streptococcus mutans. J Dent Res. 1986 Jun;65(6):918-23.

7. Carlsson J, Sundström B. Variations in composition of early dental plaque following ingestion of sucruse and glucose. Odontol Revy. 1968;19(2):161-9.

8. van Houte J, Russo J, Prostak KS. Increased pH-lowering ability of Streptococcus mutans cell masses associated with extracellular glucan-rich matrix material and the mechanisms involved. J Dent Res. 1989 Mar;68(3):451-9.

9. Rose RK, Dibdin GH, Shellis RP. A quantitative study of calcium binding and aggregation in selected oral bacteria. $\mathrm{J}$ Dent Res. 1993 Jan;72(1):78-84.

10. Margolis HC, Moreno EC. Composition of pooled plaque fluid from caries-free and caries-positive individuals following sucrose exposure. J Dent Res. 1992 Nov;71(11):1776-84.

11. Distler W, Petschelt A, Kröncke A. Protein content and wet weight of plaque microsamples. Caries Res. 1987 MayJun;21(3):200-3.

12. Tenuta LM, Del Bel Cury AA, Bortolin MC, Vogel GL, Cury JA. Ca, Pi, and $\mathrm{F}$ in the fluid of biofilm formed under sucrose. J Dent Res. 2006 Sep;85(9):834-8. surfaces is Ca concentration-dependent, but it is not affected by the presence of EPS in the biofilm matrix.

\section{Acknowledgments}

We are grateful to FAPESP for awarding scholarships to TJL and GI (Proc. 2009/12907-5 and 2008/00527-0, respectively).

13. Aires CP, Del Bel Cury AA, Tenuta LM, Klein MI, Koo H, Duarte $\mathrm{S}$, et al. Effect of starch and sucrose on dental biofilm formation and on root dentine demineralization. Caries Res. 2008 Sep;42(5):380-6.

14. Cury JA, Rebello MA, Del Bel Cury AA. In situ relationship between sucrose exposure and the composition of dental plaque. Caries Res. 1997 Sep-Oct;31(5):356-60.

15. Dubois M, Gilles KA, Hamilton JK, Rebers PA, Smith F. Colorimetric method for determination of sugars and related substances. Anal Chem. 1956 Mar;28(3):350-6.

16. Paes Leme AF, Bellato CM, Bedi G, Cury AA, Koo H, Cury JA. Effects of sucrose on the extracellular matrix of plaquelike biofilm formed in vivo, studied by proteomic analysis. Caries Res. 2008 Nov;42(6):435-43.

17. Lowry OH, Rosebrough NJ, Farr AL, Randall RJ. Protein measurement with the Folin phenol reagent. J Biol Chem. 1951 Nov;193(1):265-75.

18. Vogel GL, Chow LC, Brown WE. A microanalytical procedure for the determination of calcium, phosphate and fluoride in enamel biopsy samples. Caries Res. 1983 Jan-Feb;17(1):23-31.

19. Box GEP, Hunter WG, Hunter JS. Statistics for experimenters: an introduction to design, data analysis, and model building. New York: John Wiley \& Sons Inc.; 1978. 656 p.

20. Rose RK, Matthews SP, Hall RC. Investigation of calciumbinding sites on the surfaces of selected gram-positive oral organisms. Arch Oral Biol. 1997 Sep;42(9):595-9.

21. Rose RK, Turner SJ, Dibdin GH. Effect of $\mathrm{pH}$ and calcium concentration on calcium diffusion in streptococcal modelplaque biofilms. Arch Oral Biol. 1997 Dec;42(12):795-800.

22. Rose RK, Turner SJ. Fluoride-induced enhancement of diffusion in streptococcal model plaque biofilms. Caries Res. 1998 May-Jun;32(3):227-32.

23. Rose RK. The role of calcium in oral streptococcal aggregation and the implications for biofilm formation and retention. Biochim Biophys Acta. 2000 Jun;1475(1):76-82.

24. Vale GC, Tabchoury CP, Arthur RA, Del Bel Cury AA, Paes Leme AF, Cury JA. Temporal relationship between sucroseassociated changes in dental biofilm composition and enamel demineralization. Caries Res. 2007 Aug;41(5):406-12. 
25. Tenuta LM, Ricomini Filho AP, Del Bel Cury AA, Cury JA. Effect of sucrose on the selection of mutans streptococci and lactobacilli in dental biofilm formed in situ. Caries Res. 2006 Oct;40(6):546-9.

26. Ccahuana-Vasquez RA, Tabchoury CP, Tenuta LM, Del Bel Cury AA, Vale GC, Cury JA. Effect of frequency of sucrose exposure on dental biofilm composition and enamel demineralization in the presence of fluoride. Caries Res. 2007 Dec;41(1):9-15.
27. Rölla G, Oppermann RV, Bowen WH, Ciardi JE, Knox KW. High amounts of lipoteichoic acid in sucrose-induced plaque in vivo. Caries Res. 1980 Jul-Aug;14(4):235-8.

28. Tatevossian A. Kinetics of calcium binding and release from dental plaque. In: Rölla G, Sönju T, Embery G, editors. Tooth surface interactions and preventive dentistry. Oxford: IRL Press; 1981. p. 105-112. 